\title{
Popularization of STCR Targeted Yield for Optimum Fertilizer Use and Enhanced Yields of Maize Crop through Field Level Demonstrations
}

\author{
A. Madhavi", T. Srijaya, P. Surendra Babu and Pradip Dey
}

Jayashankar Telangana State Agricultural University, Agricultural Research Institute, Rajendranagar, Hydeabad-500030, Telangana State, India

*Corresponding author

\begin{abstract}
A B S T R A C T
Keywords

Maize, STCR,

Target yield

approach, Field

level

demonstrations,

Soil test based

fertilizer use

Article Info

Accepted:

20 July 2020

Available Online:

10 August 2020

In Telangana, nineteen FLDs were conducted in maize crop with target yield of $60 \mathrm{q} /$ ha to popularize the use of fertilizers through STCR fertilizer prescription equation. The mean initial nutrient status in these locations was $177 \mathrm{~kg} \mathrm{~N}, 53 \mathrm{~kg} \mathrm{P}_{2} \mathrm{O}_{5}$ and $288 \mathrm{~kg} \mathrm{~K}_{2} \mathrm{O} \mathrm{ha}{ }^{-1}$. On an average, the fertilizer requirement based on STCR approach for this crop was found to be $161 \mathrm{~kg}$ $\mathrm{N}, 65 \mathrm{~kg} \mathrm{P}_{2} \mathrm{O}_{5}$ and $74 \mathrm{~kg} \mathrm{~K} 2 \mathrm{O} / \mathrm{ha}$. Use of fertilizer prescription equation for maize based on soil test indicated that an amount of $\mathrm{N}_{2} \mathrm{P}_{2} \mathrm{O}_{5}$ and $\mathrm{K}_{2} \mathrm{O}$ in the range of 111 to 212,43 to 98 and 31 to $114 \mathrm{~kg} \mathrm{ha}^{-1}$ to be used by farmers to achieve $60 \mathrm{q}$ of maize /ha. However, the farmers realized yield in the range of 50 to 60 in these locations with a mean 56 q/ha due to soil test based fertilizer use. The mean economic gain variation due to change in fertilizer use and yield between use of STCR equation and farmers own method worked out to be Rs 5,885/ha.

\section{Introduction}

Maize (Zea mays L.) is the third most important food crop after rice and wheat. It is also known as queen of cereals because it has the highest genetic yield potential among the cereals. In India, the maize is used as human food $(23 \%)$, poultry feed $(51 \%)$, animal feed (12\%), industrial (starch) products $(12 \%)$, beverages and seed ( $1 \%$ each). In addition, it is basic raw material as an ingredient to thousands of industrial products that includes starch, oil, protein, alcoholic beverages, food

sweeteners, pharmaceutical, cosmetic, film, textile, gum, package and paper industries etc., In Telangana, maize occupies an area of 5.73 lakh ha. with a production of 17.51 lakh tones (DES, 2017). The grain yield of maize depends on the genetic potential of the genotype used, the characteristics of the soil, the field management practices, and agroclimatic factors (Van Ittersum et al., 1997 and Liu et al., 2018). To meet the growing demands, enhancement of maize yield in coming years across traditional and nontraditional areas is a big challenge in the era
\end{abstract}


of climate change. Meeting such challenge will only be possible through science-based technology interventions like application of novel production techniques in maize improvement, specifically the nutrient management. The soil test crop response (STCR) is cost effective and plant need based approach. The STCR approach provides principles and tools for supplying crop nutrients as and when needed to achieve higher yield. It also aim to apply nutrients at optimal rates and time to achieve higher yield and higher efficiency of nutrient use by the crop, leading to more net returns per unit of fertilizer invested. Soil test calibration permits balanced fertilization through right kind and amount of fertilizers. In this regard, targeted yield approach had been found to be beneficial recommending balanced fertilization considering the soil available nutrient status and crop needs (Ramamoorthy et al., 1967). The present investigation was under taken in farmers fields to popularize fertilizer prescription equations of yield target approach in maize. The specific yield equation based on soil health besides ensuring sustainable crop production also steers the farmers towards economic use of costly fertilizer inputs depending on their financial status and market price of the crop under consideration (Bera et al., 2006).

\section{Materials and Methods}

A field experiment was conducted in farmer's fields at nineteen different locations of Rangareddy district, Telangana State during rabi, 2017-19. The objective of present investigation was to study the influence of different nutrient management approaches on productivity of maize. Treatments comprised of 2 nutrient management approaches viz., Farmers Fertilizer practice (FFP) and STCR. In STCR approach initial soil available nutrients $\mathrm{N}, \mathrm{P}$ and $\mathrm{K}$ are required to compute the target yield equations at a particular field level. A target yield $60 \mathrm{qha}^{-1}$ was taken for a test variety of DHM-117. The required quantity of fertilizers to attain the target yield was calculated based on initial soil fertility status with the equation given below.

$\mathrm{FN}=4.00 \mathrm{~T}-0.49 \mathrm{SN}$

$\mathrm{FP}_{2} \mathrm{O}_{5}=2.15 \mathrm{~T}-2.58 \mathrm{SP}$

$\mathrm{FK}_{2} \mathrm{O}=2.58 \mathrm{~T}-0.30 \mathrm{SK}$

In the above equation, $\mathrm{FN}, \mathrm{FP}_{2} \mathrm{O}_{5}, \mathrm{FK}_{2} \mathrm{O}$ represents the fertilizer of nitrogen, phosphorus and potassium in $\mathrm{kg} \mathrm{ha}^{-1}$. T means the target yield in $\mathrm{q} \mathrm{ha}^{-1}$. SN, SP and SK are soil available $\mathrm{N}, \mathrm{P}$ and $\mathrm{K}$ respectively. Initial soil sample are collected at each location and analyzed for $\mathrm{pH}$ of the soil in 1:2.5 soil water suspensions (Jackson, 1973), electrical conductivity of the soil in 1:2.5 soil water extract (Jackson, 1973). Available nitrogen in the soil was determined by alkaline permanganate method (Subbiah and Asija, 1956). Available phosphorus content was determined by Olsen's extractant (Olsen et al., 1954). The available potassium in soil was extracted with neutral normal ammonium acetate (Jackson, 1973).Initial nutrient status across the nineteen locations has revealed that the soils are neutral to moderately alkaline in reaction, non-saline and low organic carbon in nature. Available nitrogen was low in the range of $99-263 \mathrm{~kg} \mathrm{ha}{ }^{-1}$, available phosphorus was medium to high with range of $28-72 \mathrm{~kg} \mathrm{P}_{2} \mathrm{O}_{5} \mathrm{ha}^{-1}$ and available potassium was medium to high ranging from $165-436$ $\mathrm{kg} \mathrm{ha}^{-1}$ (Table 1). The required nitrogen was applied through three splits one third at basal, one third at knee high and last dose of one third at tasseling stage while phosphorus and potassium are applied as basal.

An interaction meeting was held with farmers to know the different fertilizer application practices among them. Majority of the farmers following the fertilizer practices was considered as Farmers Fertilizer Practice 
(Table 2). It was noticed that farmers are mostly concentrating in the application of nitrogen and phosphorus fertilizers but they are applying less or zero dose of potassium. Plant protection measures were adopted as and when required. The grain yield was recorded at harvest. It was noticed that in all the locations farmers has practiced imbalance fertilizers compared to STCR recommendations.

\section{Results and Discussion}

The results has shown that the yield was in the range of 45 to $58 \mathrm{q} \mathrm{ha}^{-1}$ with a mean yield of $51 \mathrm{q} \mathrm{ha}^{-1}$ in different locations under farmers practice while in case of STCR approach was 50 to $60 \mathrm{q} \mathrm{ha}^{-1}$ with a mean yield of $56 \mathrm{q} \mathrm{ha}^{-1}$ (Table 3). In STCR technology has recorded an additional mean yield of $5 \mathrm{q} \mathrm{ha}{ }^{-1}$ over farmer fertilizer practice. The higher grain yield in STCR recommendation may be due to application of fertilizers based on needs of crop. Fertilizers in target yield approach, takes into account the crop needs and nutrients present in the soil. It may be due to coincidence of fertilizers application with critical stages of crop. It might have resulted in better assimilation of photosynthetates to grain. Similar results were obtained by Ray et al., (2000), Meena et al., (2001), Jayaprakash et al., (2006), Arun Kumar et al., (2007), Umesh (2008), Vikram et al., (2015), Pradeep kumar and Parmanand, (2018) and Prabhakar Reddy et al., (2018). It was noticed that on an average an excess amount of fertilizer cost in STCR approach was Rs. 907 per hectare over farmers practice. It may be due to balanced application of fertilizers based on soil test values rather than farmers practice of routine fertilizer application which reflects on yield of crop.

Table.1 Physico- chemical properties of selected farmer's fields

\begin{tabular}{|c|c|c|c|c|c|c|c|}
\hline Sl.No. & Farmer Name & pH & $\begin{array}{c}E C \\
\left(d^{\prime} \mathbf{S ~ m}^{-1}\right)\end{array}$ & $\begin{array}{l}\text { OC } \\
(\%)\end{array}$ & $\begin{array}{c}\mathrm{N} \\
\left(\mathrm{kg} \mathrm{ha}^{-1}\right)\end{array}$ & $\begin{array}{c}\mathbf{P}_{2} \mathrm{O}_{5} \\
\left(\mathrm{~kg} \mathrm{ha}^{-1}\right)\end{array}$ & $\begin{array}{c}\mathrm{K}_{2} \mathrm{O} \\
\left(\mathrm{kg} \mathrm{ha}^{-1}\right)\end{array}$ \\
\hline 1 & M.Goobriya & 7.98 & 0.223 & 0.41 & 251 & 54 & 289 \\
\hline 2 & M.Taarya & 7.76 & 0.195 & 0.19 & 163 & 56 & 247 \\
\hline 3 & M.Puliya & 7.89 & 0.326 & 0.34 & 213 & 39 & 236 \\
\hline 4 & M.Baliya & 7.78 & 0.646 & 0.22 & 188 & 52 & 173 \\
\hline 5 & M.Teekiya & 7.98 & 0.406 & 0.25 & 188 & 46 & 224 \\
\hline 6 & M.Keshya & 8.1 & 0.192 & 0.32 & 188 & 28 & 190 \\
\hline 7 & M.Kishan & 7.52 & 0.112 & 0.38 & 254 & 44 & 209 \\
\hline 8 & M.Baashya & 7.64 & 0.12 & 0.21 & 150 & 58 & 165 \\
\hline 9 & M.Lali & 7.87 & 0.229 & 0.39 & 263 & 52 & 222 \\
\hline 10 & M.Chakriya & 7.07 & 0.096 & 0.32 & 201 & 49 & 436 \\
\hline 11 & Mudanath Rathan & 7.89 & 0.326 & 0.34 & 213 & 39 & 236 \\
\hline 12 & Mudanath Krishna & 7.78 & 0.646 & 0.22 & 188 & 52 & 173 \\
\hline 13 & Mudanath Mangya & 7.07 & 0.096 & 0.32 & 201 & 49 & 436 \\
\hline 14 & P.Shankar & 7.13 & 0.418 & 0.24 & 113 & 70 & 405 \\
\hline 15 & P.Dhasiya & 6.96 & 0.192 & 0.18 & 99 & 67 & 357 \\
\hline 16 & P.Venkataiah & 7.25 & 0.164 & 0.32 & 101 & 63 & 344 \\
\hline 17 & Eshwar & 8.02 & 0.433 & 0.25 & 145 & 66 & 364 \\
\hline 18 & Mallesh & 7.83 & 0.291 & 0.19 & 113 & 58 & 402 \\
\hline \multirow[t]{2}{*}{19} & Srinivas & 7.67 & 0.442 & 0.27 & 132 & 72 & 372 \\
\hline & Mean & 7.64 & 0.292 & 0.28 & 177 & 53 & 288 \\
\hline
\end{tabular}


Table.2 Fertilizer application rates in FFP and STCR

\begin{tabular}{|c|c|c|c|c|c|c|c|}
\hline \multirow[t]{2}{*}{$\begin{array}{l}\text { Sl. } \\
\text { No. }\end{array}$} & \multirow[t]{2}{*}{ Farmer Name } & \multicolumn{3}{|c|}{$\begin{array}{l}\text { Farmer Fertilizer Practice (FFP) } \\
\qquad\left(\mathrm{kg} \mathrm{ha}^{-1}\right)\end{array}$} & \multicolumn{3}{|c|}{$\begin{array}{l}\text { STCR Fertilizer Recommendation } \\
\qquad\left(\mathrm{kg} \mathrm{ha}^{-1}\right)\end{array}$} \\
\hline & & $\mathbf{N}$ & $\mathbf{P}_{2} \mathrm{O}_{5}$ & $\mathrm{~K}_{2} \mathrm{O}$ & $\mathbf{N}$ & $\mathbf{P}_{2} \mathrm{O}_{5}$ & $\mathbf{K}_{2} \mathbf{O}$ \\
\hline 1 & M.Goobriya & 138 & 58 & 0 & 117 & 68 & 83 \\
\hline 2 & M.Taarya & 138 & 88 & 0 & 160 & 66 & 93 \\
\hline 3 & M.Puliya & 115 & 28 & 0 & 136 & 85 & 96 \\
\hline 4 & M.Baliya & 130 & 30 & 0 & 148 & 70 & 112 \\
\hline 5 & M.Teekiya & 125 & 88 & 0 & 148 & 77 & 99 \\
\hline 6 & M.Keshya & 100 & 75 & 0 & 148 & 98 & 107 \\
\hline 7 & M.Kishan & 125 & 58 & 0 & 116 & 79 & 103 \\
\hline 8 & M.Baashya & 115 & 30 & 0 & 167 & 64 & 114 \\
\hline 9 & M.Lali & 130 & 75 & 0 & 111 & 70 & 99 \\
\hline 10 & M.Chakriya & 120 & 80 & 0 & 142 & 74 & 46 \\
\hline 11 & Mudanath Rathan & 128 & 62 & 35 & 166 & 64 & 58 \\
\hline 12 & Mudanath Krishna & 132 & 58 & 30 & 176 & 55 & 66 \\
\hline 13 & Mudanath Mangya & 118 & 52 & 35 & 171 & 57 & 31 \\
\hline 14 & P.Shankar & 215 & 100 & 30 & 206 & 43 & 35 \\
\hline 15 & P.Dhasiya & 197 & 82 & 35 & 212 & 45 & 42 \\
\hline 16 & P.Venkataiah & 189 & 72 & 30 & 211 & 47 & 44 \\
\hline 17 & Eshwar & 224 & 112 & 44 & 169 & 55 & 64 \\
\hline 18 & Mallesh & 208 & 94 & 34 & 185 & 64 & 54 \\
\hline \multirow[t]{2}{*}{19} & Srinivas & 245 & 103 & 42 & 175 & 48 & 62 \\
\hline & Mean & 152 & 71 & 17 & 161 & 65 & 74 \\
\hline
\end{tabular}

Table.3 Grain yield and change in grain yield of maize between FFP and STCR

\begin{tabular}{|c|c|c|c|c|c|c|c|}
\hline \multirow[t]{2}{*}{$\begin{array}{l}\text { Sl. } \\
\text { No }\end{array}$} & \multirow[t]{2}{*}{ Farmers Name } & \multicolumn{2}{|c|}{$\begin{array}{l}\text { Grain Yield } \\
\left(\mathbf{q} \text { ha }^{-1}\right)\end{array}$} & \multirow{2}{*}{$\begin{array}{l}\text { Change in } \\
\text { grain yield } \\
\text { over FFP }\end{array}$} & \multicolumn{2}{|c|}{$\begin{array}{l}\text { Total cost of fertilizers } \\
\left(\text { Rs. ha }{ }^{-1}\right)\end{array}$} & \multirow{2}{*}{$\begin{array}{l}\text { Difference in amoun } \\
\text { of fertilizers in FFP } \\
\text { over STCR }\end{array}$} \\
\hline & & FFP & STCR & & FFP & STCR & \\
\hline 1 & M.Goobriya & 45 & 50 & 5 & 4870 & 6763 & -1893 \\
\hline 2 & M.Taarya & 58 & 60 & 2 & 6487 & 7398 & -911 \\
\hline 3 & M.Puliya & 53 & 60 & 7 & 2963 & 8168 & -5205 \\
\hline 4 & M.Baliya & 50 & 58 & 8 & 3290 & 7837 & -4547 \\
\hline 5 & M.Teekiya & 50 & 56 & 6 & 6326 & 7937 & -1611 \\
\hline 6. & M.Keshya & 53 & 58 & 5 & 5330 & 9233 & -3903 \\
\hline 7 & M.Kishan & 48 & 52 & 4 & 4709 & 7735 & -3026 \\
\hline 8 & M.Baashya & 54 & 60 & 6 & 3097 & 7751 & -4654 \\
\hline 9 & M.Lali & 48 & 54 & 6 & 5717 & 7130 & -1413 \\
\hline 10 & M.Chakriya & 55 & 57 & 2 & 5857 & 6678 & -821 \\
\hline 11 & Mudanath Rathan & 50 & 54 & 4 & 4369 & 5274 & -905 \\
\hline 12 & Mudanath Krishna & 52 & 53 & 1 & 4040 & 5118 & -1078 \\
\hline 13 & Mudanath Mangya & 49 & 59 & 10 & 3862 & 4135 & -273 \\
\hline 14 & P.Shankar & 53 & 59 & 6 & 10038 & 7402 & +2636 \\
\hline 15 & P.Dhasiya & 51 & 57 & 6 & 9018 & 7568 & +1450 \\
\hline 16 & P.Venkataiah & 54 & 56 & 2 & 8476 & 7674 & +802 \\
\hline 17 & Eshwar & 47 & 56 & 9 & 10679 & 7475 & +3204 \\
\hline 18 & Mallesh & 50 & 53 & 3 & 9685 & 8074 & +1611 \\
\hline \multirow[t]{2}{*}{19} & Srinivas & 48 & 52 & 4 & 10552 & 7244 & +3308 \\
\hline & Mean & 51 & 56 & 5 & 6282 & 7189 & +907 \\
\hline
\end{tabular}


Table.4 Comparative study of grain yield, gross return and net profit of maize between FFP and STCR

\begin{tabular}{|c|c|c|c|c|c|c|c|c|c|c|}
\hline \multirow[t]{2}{*}{ S.No } & \multirow[t]{2}{*}{ Farmer Name } & \multicolumn{2}{|c|}{$\begin{array}{l}\text { Seed yield } \\
\quad\left(\mathbf{q} \mathbf{h a}^{-1}\right)\end{array}$} & \multicolumn{2}{|c|}{$\begin{array}{l}\text { Total cost of } \\
\text { fertilizers } \\
\left(\text { Rs. ha }^{-1}\right)\end{array}$} & \multicolumn{2}{|c|}{$\begin{array}{l}\text { Gross Returns } \\
\quad\left(\text { Rs. } \mathbf{h a}^{-1}\right)\end{array}$} & \multicolumn{2}{|c|}{$\begin{array}{l}\text { Gross Returns } \\
\text { over Fertilizer } \\
\text { cost }\left(\text { Rs. ha }{ }^{-1}\right)\end{array}$} & \multirow[t]{2}{*}{$\begin{array}{c}\text { Relative } \\
\text { income ( } R \text { s. } \\
\text { Over FFP) }\end{array}$} \\
\hline & & FFP & STCR & FFP & STCR & FFP & STCR & FFP & STCR & \\
\hline 1 & M.Goobriya & 45 & 50 & 4870 & 6763 & 54000 & 60000 & 49130 & 53237 & 4107 \\
\hline 2 & M.Taarya & 58 & 60 & 6487 & 7398 & 69600 & 72000 & 63113 & 64602 & 1489 \\
\hline 3 & M.Puliya & 53 & 60 & 2963 & 8168 & 63600 & 72000 & 60637 & 63832 & 3195 \\
\hline 4 & M.Baliya & 50 & 58 & 3290 & 7837 & 60000 & 69600 & 56710 & 61763 & 5053 \\
\hline 5 & M.Teekiya & 50 & 56 & 6326 & 7937 & 60000 & 67200 & 53674 & 59263 & 5589 \\
\hline 6 & M.Keshya & 53 & 58 & 5330 & 9233 & 63600 & 69600 & 58270 & 60367 & 2097 \\
\hline 7 & M.Kishan & 48 & 52 & 4709 & 7735 & 57600 & 62400 & 52891 & 54665 & 1774 \\
\hline 8 & M.Baashya & 54 & 60 & 3097 & 7751 & 64800 & 72000 & 61703 & 64249 & 2546 \\
\hline 9 & M.Lali & 48 & 54 & 5717 & 7130 & 57600 & 64800 & 51883 & 57670 & 5787 \\
\hline 10 & M.Chakriya & 55 & 57 & 5857 & 6678 & 66000 & 68400 & 60143 & 61722 & 1579 \\
\hline 11 & $\begin{array}{l}\text { Mudanath } \\
\text { Rathan }\end{array}$ & 50 & 54 & 4369 & 5274 & 55000 & 59400 & 50631 & 54126 & 3495 \\
\hline 12 & $\begin{array}{l}\text { Mudanath } \\
\text { Krishna }\end{array}$ & 52 & 53 & 4040 & 5118 & 57200 & 64900 & 53160 & 59782 & 6622 \\
\hline 13 & $\begin{array}{l}\text { Mudanath } \\
\text { Mangya }\end{array}$ & 49 & 59 & 3862 & 4135 & 53900 & 58300 & 50038 & 54165 & 4127 \\
\hline 14 & P.Shankar & 53 & 59 & 10038 & 7402 & 90865 & 101235 & 80827 & 93833 & 13006 \\
\hline 15 & P.Dhasiya & 51 & 57 & 9018 & 7568 & 86785 & 96348 & 77767 & 88780 & 11013 \\
\hline 16 & P.Venkataiah & 54 & 56 & 8476 & 7674 & 91503 & 95710 & 83027 & 88036 & 5009 \\
\hline 17 & Eshwar & 47 & 56 & 10679 & 7475 & 79900 & 95200 & 69221 & 87725 & 18504 \\
\hline 18 & Mallesh & 50 & 53 & 9685 & 8074 & 85000 & 90100 & 75315 & 82026 & 6711 \\
\hline \multirow[t]{2}{*}{19} & Srinivas & 48 & 52 & 10552 & 7244 & 81600 & 88400 & 71048 & 81156 & 10108 \\
\hline & Mean & 51 & 56 & 6282 & 7189 & 68345 & 75136 & 62063 & 67947 & 5885 \\
\hline
\end{tabular}

Relative income gain due to fertilizer use and yield between the two treatments was found to be in the range of Rs 1489 to $18,504 /$ - with a mean of Rs 5,885/ha (Table 4). This may be due to higher productivity and gross returns in the STCR treatment over the farmer fertilizer practice treatment. It might be also due to nutrient balance in soil due to soil test based fertilizer application and nutrient reserves in the soil. Similar results are reported by Pradeep kumar and Parmanand (2018).

This study indicated that the soil test based fertilizer application gave better outcome over farmers fertilizer recommendation due to balanced nutrient management.

\section{References}

Arun Kumar, Gali SK and Hebsur S.2007. Effect of different levels of NPK on growth and yield parameters of sweet corn. Karnataka J. Agric. Sci. 20(1): 4143.

Bera R, Seal A, Bhattacharyya P, Das T H, Sarkar D and Kangjoo K. 2006. Targeted yield concept and a framework of fertilizer recommendation in irrigated 
rice domains of subtropical India. Journal of Zhejiang Univ Sci. 7(12): 963- 968.

DES.2017. Directorate of Economics and Statistics, Statistical Abstracts, Government of Telangana.

Jackson M L. 1973. Soil chemical analysis, prentice Hall of India Pvt. Ltd., New Delhi.

Jayaprakash TC, Nagalikar VP, Pujari BT and Setty RA. 2006. Effect of organics and inorganics on growth and yield of maize under irrigation. Karnataka J. Agric. Sci. 18(3): 798.

Liu Z, Yang X, Lin X, Hubbard KG, Lv S, Wang J.2016. Narrowing the agronomic yield gaps of maize by improved soil, cultivar, and agricultural management practices in different climate zones of Northeast China. Earth Interact 20: 1-18.

Meena M, Ahmed S, Riazuddin M, Chandrasekhara KR, Rao BRCP. 2001. Soil Test crop response calibration studies on onion (Allium cepa) in Alfisols. Jnal of Indian Society of Soil Science 49: 709-713

Olsen SR, Cole CW, Watanable FS and Dean LA. 1954. Estimation of Available Phosphorus in Soils by Extraction with Sodium Bicarbonate. United States Department Agricultural Circular No. 639.

Prabhakar Reddy T, Madhavi A, Srijaya T and Vijayalakshmi D. 2018. Field validation of soil test and yield target based fertilizer prescription equation for soybean on Vertisol. Journal of pharmacognosy and phytochemistry. 7(6): 1159-1162.

Pradeep kumar and Parmanand.2018.Evaluation of soil test crop response approach for sustainable crop production of rice in Baladobazar - Bhatapara district of Chhattisgarh. International Journal of current microbiology and applied science Special Issue 7:3513- 3518.

Ramamoorthy B, Narsimhan R L and Dinesh R S. (1967). Fertilizer application for specific yield targets of Sonora64(wheat). Indian Farming. 25(5): 43 45.

Ray PK, Jana AK, Maitra DN, Saha MN, Chaudhury J, Saha S, Saha AR. 2000. Fertilizer Prescription for soil test basis for jute, rice and wheat in Typic Ustrochept. Journal of Indian Society of Soil Science 48: 79-84.

Subbiah BV and Asija GL. 1956. a. Rapid Procedure for the determination of available nitrogen in Soil. Current Science. 25: 226-230.

Umesh M R.2008. Investigation on balanced fertilization for maize- pigeonpea cropping sequence in Alfisols of Karnataka. Ph.D. Thesis. Univ. Agric. Sci., Bangalore.

Van Ittersum MK, Rabbinge R.1997. Concepts in production ecology for analysis and quantification of agricultural inputoutput combinations. Field Crops Res. 52, 197-208.

Vikram AP, Birdar DP, Umesh MR, Basavanneppa M A and Narayana Rao K. 2015. Effect of nutrient management techniques on growth, yield and economics of hybrid maize (Zea mays L.) in vertisols. Karnataka J. Agric. Sci. 28(4): 477-481

\section{How to cite this article:}

Madhavi, A., T. Srijaya, P. Surendra Babu and Pradip Dey. 2020. Popularization of STCR Targeted Yield for Optimum Fertilizer Use and Enhanced Yields of Maize Crop through Field Level Demonstrations. Int.J.Curr.Microbiol.App.Sci. 9(08): 2209-2214. doi: https://doi.org/10.20546/ijcmas.2020.908.252 